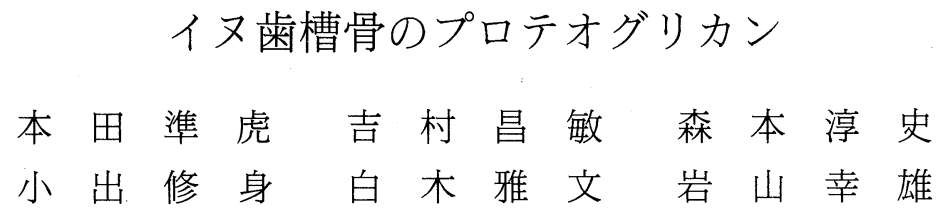

朝日大学歯学部歯周病学講座

(主任：岩山幸雄)

(平成 3 年 9 月 18 日受付)

\title{
Proteoglycans in Alveolar and Non-Alveolar Regions of Canine Mandibular Bone
}

Junko HONDA, Masatoshi YOSHIMURA, Atsushi MORIMOTO, Osami KOIDE, Masafumi SHIRAKI and Yukio IWAYAMA

Department of Periodontology, Asahi University School of Dentistry

1851-1 Hozumi, Hozumi-cho, Motosu-gun, Gifu, 501-02, Japan

(Chief : Prof. Yukio IWAYAMA)

Proteoglycans in alveolar and non-alveolar regions of canine mandibular bone were extracted and separated by gel-filtration and SDS-polyacrylamide gel electrophoresis. Furthermore, qualitative and quantitative analysis of glycosaminoglycans liberated from these proteoglycans was performed to characterize the proteoglycans in alveolar bone as compared to those in non-alveolar bone. Proteoglycans in bone tissues were successfully extracted under demineralizing conditions achieved in the presence of $0.25 \mathrm{M}$ ethylenediaminetetraacetic acid. The amount of proteoglycan in alveolar bone was less than $50 \%$ of that in non-alveolar bone. The molecular weights of proteoglycans partially purified by $\mathrm{CsCl}$ centrifugation ranged from 70,000 to 76,000 . It is possible that two different low molecular weight forms exist in bone. The glycosaminoglycans extracted from the proteoglycans consisted mainly of chondroitin sulfate in both alveolar and non-alveolar bones.

Key words : Proteoglycans, Glycosaminoglycans, Canine alveolar bone

要旨：イ邓下頭骨より歯槽骨と非歯槽骨を摘出, プロテオグリカンを抽出し，これをゲル濾過カラムを用いた HPLC と SDS-PAGE により検索した。さらにプロテオグリカンから分離, 精製したグリコサミングリカンを定性, 定量分析し, 歯槽骨プロテオグリカンの特徵を非歯槽骨プロテオグリカンとの比較において検討し, 次の結果を得 た。骨組織中のプロテオグリカンは脱灰条件（0.25 M EDTA）下で，効率よく抽出された。しかし，歯槽骨のプ ロテオグリカン量は非歯槽骨に比べて $1 / 2$ 以下であった。C C C 沈降平衡遠心で得られた粗精製プロテオグリカン は分子量 $76 \mathrm{kDa}$ と $70 \mathrm{kDa}$ の 2 種類の低分子型プロテオグリカンと推察された。一方, プロテオグリカンから分 離, 精製したグリコサミノグリカンは, 歯槽骨, 非歯槽骨ともにコンドロイチン硫酸が主要成分であった。

索引用語：プロテオグリカン，グリコサミノグリカン，イヌ歯槽骨 


\section{緒言}

プロテオグリカン $(\mathrm{PG})$ は，細胞外マトリックスの 構成成分としてコラーゲン，非コラーゲン性糖タンパ ク質とともに広く結合組織に分布する基質成分の 1 つ であり，水分保持，イオンの調節，コラーゲン線維形 成，骨形成などに関与している ${ }^{1,2)}$ 。その典型的分子形 態は, 軟骨のものについて詳細に研究3,4)され, 分子量 約 $2 \times 10^{6}$ の約 $10 \%$ を占めるコアタンパク質に 50,60 本の分子量約 $30 \mathrm{kDa}$ のコンドロイチン硫酸 $(\mathrm{CS})$ 鎖 が linkage region を介して結合したものである。さら に分子量約 $6 \mathrm{kDa}$ のケラタン硫酸 $(\mathrm{KS})$ などが結合し た複雑な形態をとる。また，構造とおそらく機能も相 当に異なると思われる分子量の小さい $\mathrm{PG}$ の存在が知 られている5)。PG はこれら多彩な生理的機能の他, 組 織の炎症と密接に関連している事も明らかにされてい $る^{6,7)}$ 。

一方，歯肉溝滲出液 $(\mathrm{GCF})$ は，歯周炎による歯周 組織の破壞程度や代謝性変化を反映し，病態を鋭敏に 捉える一指標になる可能性があるとして注目されてい る ${ }^{8)}$ 。特に GCF 成分の 1 つとして知られるグリコサミ ノグリカン $(\mathrm{GAG})$ の質的量的変動は，歯周炎の病態 との相関の面から, 種々の研究9 11) が成されている。梶 川ら ${ }^{12)}$ の行ったヒト実験的歯肉炎に於ける GCF -GAG の検索では，健常時ではヒアルロン酸 (HA) の みが認められ，歯肉炎時に他の GAG は認められな かったものの, HA は明らかに増加する傾向があると 報告している。永橋 ${ }^{13}$ は成人型歯周炎患者の GCF -GAG について分析を行った結果, 治療前に認められ た HA およびデルマタン硫酸 (DS) が，歯周初期治療 後では HA の顕著な減少と DS が消失した事を示し ている。また Last ら ${ }^{10}$ は, 進行した歯周炎患者の GCF 中には単なる歯肉炎患者では認められない $\mathrm{GAG}$ が出 現し，これはコンドロイチン-4-硫酸であると報告し， さらに矯正による歯牙移動中の圧迫側の GCF 中には CS が存在する事を示した ${ }^{14)}$ 。歯周組織の状態の違いに よる,これら GCF 中の GAG の質的, 量的変動は, そ の供給源として考えられる組織の炎症程度に深く関与 すると思われる。

歯周炎は歯槽骨の吸収という破壊性変化を特徴とす る病変であり, 重度歯周炎時に歯槽骨が多量且つ急速 に吸収されることから，GCF-GAG の供給源として， 骨破壊産物が歯周ポケットから漏出する可能性が考え
られる。顎骨体においても，とりわけ歯槽骨は咀嚼時 の機能圧を受けとめる部位としてなど，非歯槽骨部と は生理的環境が異なる。これら環境の違いから骨基質 成分の質的量的差異が生じる可能性も考えられる。 従って歯槽骨由来の GCF-GAG を捉えることは歯周 炎の病態を的確に把握するための有効な手がかりとな る。しかしながら, 歯槽骨中の GAG やこれにより構成 されるプロテオグリカン $(\mathrm{PG})$ に関する報告は少なく, Waddington ら ${ }^{15)}$ の報告など若干が認められる ${ }^{16,17) の ~}$ みである。そこで，歯槽骨 PG および GAG が GCF 成 分の 1 つとして出現する可能性を検索する目的で，イ 又下顎骨歯槽骨中の PG の特徵について, 非歯槽骨中 の PG と比較しながら検討した。

\section{実験材料および方法}

\section{1. 試料の調製および抽出方法}

図 1 亿歯槽骨および非歯槽骨 PG の抽出方法とその 精製過程の概要を示す。雑種成犬 2 頭より下顎骨を摘 出し, 骨髄, 骨膜およびその他の軟組織を除去した後, 歯槽骨部と非歯槽骨部に分離した。分離基準として, 歯槽骨部は下顎管上部で抜歯窩に接する部位を，非歯 槽骨部は下䫇管下部より下顎骨底部に至る抜歯窩から 充分離れた部位を選択した。これら試料は粉末とし， $0.5 \mathrm{~mm}$ メッシュに篩過したものを用いた。抽出は Termine ら ${ }^{18)}$ の方法に準じて行った。組織の湿重量 30 $\mathrm{g}$ に対し未脱灰条件下に 100 倍量の $4 \mathrm{M}$ 塩酸グアニ ジンを含む $50 \mathrm{mM}$ トリス緩衝液（pH 8.0）（Gd-緩衝 液) で 72 時間抽出 (Gd-extract) 後, 脱灰条件 $(0.25$ M EDTA)下に同緩衝液中で 48 時間抽出 (E-extract) を行った。上記の操作はいずれも $4^{\circ} \mathrm{C} て ゙$ でい, 緩衝液

\begin{tabular}{|c|c|}
\hline $\begin{array}{l}\text { イヌ下顎骨 } \\
\mid\end{array}$ & （歯槽骨，非歯槽骨） \\
\hline 未脱灰抽出 & $\begin{array}{l}4 \mathrm{M} \mathrm{Gd}-\mathrm{HCl} / 50 \mathrm{mM} \text { Tris- } \mathrm{HCl}, \mathrm{pH} 8.0, \\
=(\mathrm{Gd} \text {-buffer }) \text {, proteinase inhibitors }\end{array}$ \\
\hline 脱灰抽出 & $\begin{array}{l}0.25 \mathrm{M} \text { EDTA, Gd-buffer, } \\
\text { proteinase inhibitors }\end{array}$ \\
\hline \multicolumn{2}{|c|}{$\mathrm{CsCl}$ 沈降平衡遠心 } \\
\hline & $\begin{array}{l}0.5 \mathrm{M} \mathrm{Gd}-\mathrm{HCl} / 50 \mathrm{mM} \text { Tris }-\mathrm{HCl} \text {, } \\
\rho=1.6 \mathrm{~g} / \mathrm{m} l \text {, proteinase inhibitors }\end{array}$ \\
\hline 粗精製プロラ & ·グリカン画分 \\
\hline
\end{tabular}

図 1 プロテオグリカンの抽出及び精製方法 


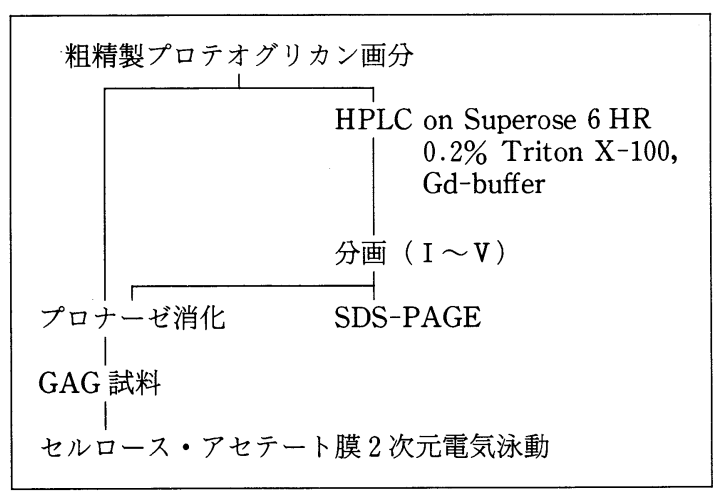

図 2 粗精製プロテオグリカンの分析経過

中にはタンパク質分解酵素阻害剂として, $0.01 \mathrm{M} \mathrm{N}$ ーエチルマレイミド (NEM), $1 \mathrm{mM}$ フェニルメタンス ルホニルフルオリド (PMSF), $0.1 \mathrm{M} \mathrm{6-アミノへキサ}$ ン酸 (以上, 生化学工業, 東京) を加えた。得られた 抽出液の一部についてウロン酸, およびタンパク質量 を測定した。タンパク質の定量はウシ血清アルブミン


ロン酸量はグルクロン酸量として硫酸カルバゾール 法20)で行った。

2. プロテオグリカンの精製 ( $\mathrm{CsCl}$ 沈降平衡遠心) Hascall とSajdera ${ }^{21)}$ による方法に準じて行った。 抽出液は限外濾過濃縮後, 塩酸グアニジンだけを含ま ない抽出溶液に対して 3 日間透析し, 引き続き $0.5 \mathrm{M}$ 塩酸グアニジンを含む抽出溶液に 4 日間同処理を行っ た。次に塩化セシウムを加え比重 $1.6 \mathrm{~g} / \mathrm{m} l$ となるよ うに調製した。10,000 rpm, 30 分間の遠心で浮遊沈澱 を除去した後, $35,000 \mathrm{rpm}, 10^{\circ} \mathrm{C}, 72$ 時間遠心した。 10 の画分（底部より Al-A 10）に分画し, 各画分の夕 ンパク質量およびウロン酸量の測定を行った。タンパ ク質/ウロン酸比の高值を示す画分を回収し, $0.5 \mathrm{M}$ 酢 酸ナトリウム緩衝液 $(\mathrm{pH} 7.0)$ に 48 時間, 引き続き蒸 留水に対し 72 時間透析した後, 粗精製 PG 画分とし て $-80^{\circ} \mathrm{C}$ 凍結保存した。図 2 に以後行った粗精製 $\mathrm{PG}$ 画分の分析経過の概要を示す。

\section{3. 高速液体クロマトグラフィー（HPLC）}

得られた粗精製 PG 画分はゲル濾過カラムを用いた HPLC 法で溶出分離を行った。分離にはSuperose 6 HR 10/30 カラム (Pharmacia) を接続したファルマシ ア FPLC システムを用い, 溶出溶媒は $0.2 \%$ Triton X -100 を含む $\mathrm{Gd}$-緩衝液で流速 $0.5 \mathrm{ml} / \mathrm{min}$ で溶出し, 検出は $280 \mathrm{~nm}$ の紫外吸収で行った。溶出液は, 各ピー
クごとに回収し，ウロン酸量を測定した。なお，分子 量マーカーとして, チログロブリン $(669 \mathrm{k})$, フェリチ ン $(440 \mathrm{k})$, アルドラーゼ $(158 \mathrm{k})$, キモトリプシノー ゲン $(25 \mathrm{k})$ を用いた。各ピークは再度限外濾過法によ り脱塩, 濃縮し, 次の実験に供した。

\section{SDS 電気泳動 (SDS-PAGE)}

HPLCにより得られた各ピークは, Laemmli ${ }^{22)}$ の方 法に準じた SDS-PAGEを行った。

分離には $12 \% \mathrm{~T}$ スラブゲルを用い, $2 \mathrm{~mA} /$ ウルで 100 分間の泳動を行った。分子量マーカーはSDS -PAGE 用 calibration protein (Boehringer Mannheim Combithek ${ }^{\circledR)}$ を用いた。すなわち，フォスフォ リラーゼ b $(97,4 \mathrm{k})$, グルタメイトデヒドロゲナーゼ $(55,4 \mathrm{k})$, ラクテイトデヒドロゲナーゼ $(36,5 \mathrm{k})$, ト リプシンインヒビター $(20,1 \mathrm{k})$ を含むものである。染 色には PAGEタンパク質銀染色用シルベストステイ ンキット（ナカライテスク，京都）を用いた。

\section{GAG の調製}

$\mathrm{CsCl}$ 沈降平衡遠心法により得られた粗精製 $\mathrm{PG}$ 画 分に対し乾燥重量の 30 倍量の $0.5 \mathrm{~N}$ 水酸化ナトリウ ムを加え, $4^{\circ} \mathrm{C}, 20$ 時間のアルカリ処理を行い, これを $1 \mathrm{M}$ 塩酸で中和した後, $5 \mathrm{mM}$ 塩化カルシウムを含む $0.1 \mathrm{M}$ トリス緩衝液 ( $\mathrm{pH} 7.8$ )を加えて $100^{\circ} \mathrm{C}, 30$ 分 間の煮沸によるタンパク質の熱変性を行った。次いで, プロナーゼ E ( 70,000 p.u.k./g, 科研科学, 東京) を加 え, $50^{\circ} \mathrm{C}, 48$ 時間酸素処理を行った。反応停止と酵素 タンパク除去のため, 終濃度 10\%トリクロロ酢酸 $(\mathrm{w} /$ v) を加え $4^{\circ} \mathrm{C}, 1$ 時間静置した。これを $10,000 \mathrm{~g}, 10$ 分間遠沈して, 得られた上清に $5 \%$ 酶酸カリウム $(\mathrm{w} /$ v) を含む 3 倍容のエ夕ノールを加えて， $4^{\circ} \mathrm{C}, 24$ 時間 静置した。更にこれを $12,000 \mathrm{~g}, 15$ 分間遠沈して, 得 られた沈渣を蒸留水に対して透析, 凍結乾燥して GAG 試料を得た。

\section{GAGの分析}

1）セルロースアセテート膜電気泳動による分離 電気泳動膜は Separax（常光産業, 東京）を用い, Hata と $\mathrm{Nagai}^{23)}$ の方法に準じて 2 次元電気泳動を 行った。すなわち, $0.1 \mathrm{M}$ ピリジン $-0.47 \mathrm{M}$ ギ酸緩衝 液 $(\mathrm{pH} 3.0)$ を用い, 1 次元方向に $1 \mathrm{~mA} / \mathrm{cm}, 90$ 分間 泳動し, 次いでこれを $0.1 \mathrm{M}$ 酢酸バリウム溶液 （pH 8.0）を用いて 2 次元方向に $1 \mathrm{~mA} / \mathrm{cm}, 4.5$ 時間 の泳動を行った。染色には $0.1 \%$ アルシアンブルー8 $\mathrm{GX}(0.1 \%$ 酶酸溶液中) を用い 10 分間行った。脱色に は $0.1 \%$ 酶酸溶液を用い 20 分間行った。なお, GAG 
表 1 抽出効率

\begin{tabular}{|c|c|c|c|c|}
\hline \multirow[t]{3}{*}{ (a) } & \multicolumn{4}{|c|}{ 定量值 } \\
\hline & \multicolumn{2}{|c|}{ 末脱灰 } & \multicolumn{2}{|c|}{ 脱 灰 } \\
\hline & ウロン酸 & タンパク質 & ウロン酸 & タンパク質 \\
\hline 歯槽骨 & 0.10 & 8.60 & 0.76 & 5.76 \\
\hline \multirow[t]{2}{*}{ 非歯槽骨 } & 0.10 & 5.00 & 1.77 & 9.76 \\
\hline & & & \multicolumn{2}{|c|}{$\mathrm{mg} / \mathrm{g}$ of bone } \\
\hline \multirow[t]{2}{*}{ (b) } & \multicolumn{4}{|c|}{ ウロン酸/タンパク質 } \\
\hline & 未脱灰抽出 & 脱灰抽出 & \multicolumn{2}{|c|}{ 脱灰抽出/未脱灰抽出 } \\
\hline 歯槽骨 & 0.01 & 0.132 & \multicolumn{2}{|c|}{11.34} \\
\hline 非歯槽骨 & 0.02 & 0.182 & \multicolumn{2}{|c|}{9.04} \\
\hline
\end{tabular}

(a) ウロン酸及びタンパク質の定量值 数值は骨湿重 量に対する值を示す。(b) ウロン酸/タンパク質比 数 值はウロン酸/タンパク質重量比を示す。

の標準試料として HA, CS, DS, KS, ヘパラン硫酸 （HS）（以上，生化学工業）を用いた。

2）酵素消化法による同定

各 GAG は，その易動度ならびに酵素消化法により 同定した。すなわち，HA は放線菌ヒアルロニダーゼ (生化学工業) 消化により，CS と DS はコンドロイチ ナーゼ ACII およびコンドロイチナーゼ ABC (生化学 工業)消化により, KS にはケラタナーゼ(生化学工業) 消化により，HSにはへパリチナーゼ (生化学工業) 消 化により消失するスポットとして同定した。

\section{3） GAGの定量}

セルロースアセテート膜上に染色された各 $\mathrm{GAG}$ を 2 波長クロマトスキャナー（島津 CS-930）により測定 した。すなわち，アルシアンブルーに対する吸光度を $615 \mathrm{~nm}$ で，バックグランドに対する吸光度を $471 \mathrm{~nm}$ で測定し，標準試料より得られた検量線から各 GAG 量を算出した。

\section{結果}

\section{1. 歯槽骨および非歯槽骨プロテオグリカン（PG） の抽出および精製}

1) 抽出効率

表 1 に抽出効率を示す。（a ）はウロン酸およびタン パク質の定量值を，（b ）はウロン酸/タンパク質比を 示す。歯槽骨では, 未脱灰抽出に対して約 8 倍のウ口 ン酸が脱灰抽出で認められたが, 逆にタンパク質の抽 出量は, 未脱灰抽出が脱灰抽出量よりも上回った $(\mathrm{Ed}$ -extract：各 0.10,8.60 E-extract：各 $0.76,5.76$ $\mathrm{mg} / \mathrm{g})$ 。非歯槽骨では, ウロン酸, タンパク質ともに 脱灰条件下で効率よく抽出された（Ed-extract：各 $0.10,5.00$ E-extract：各 $1.77,9.76 \mathrm{mg} / \mathrm{g})$ 。ウロン 酸/タンパク質比に着目した未脱灰抽出に対する脱灰 抽出効率比は歯槽骨, 非歯槽骨それぞれ $11.34,9.04$ と 高い值を示した。

2) $\mathrm{CsCl}$ 沈降平衡遠心

図 3 に歯槽骨 ( a ) および非歯槽骨 ( b ) の E-extract の $\mathrm{CsCl}$ 沈降平衡遠心による分離パターンを示す。歯 槽骨 E-extract の分離状態は, タンパク質量は A 2 が 最も低く,A 8 までは徐々に上昇し A 9 および A 10 で は顕著な上昇を認め，またA 1 でわずかに上昇した。 ウロン酸量は, A 1 で最も高い值を示し A 3 から A 8 まではほほ一定し A 9 およびA 10で再び増加した。 ウロン酸/タンパク質比はフラクション A 1 および A 2 にそのピークを認め, 以後順に減少を認めた。非歯 槽骨においても同様の傾向が認められた。ウロン酸/夕 ンパク質比が高值を示すフラクション A 1 および A 2 を回収し，粗精製 PG 画分とした。

\section{2. 粗精製 PG 画分の HPLC による溶出分離}

図 4 に歯槽骨（a）および非歯槽骨（b）の粗精製 PG 画分のゲル濾過カラムを用いた溶出パターンを示 す。ボイドボリュームにより 5 つの蛋白ピーク（ピー ク I : 13-18, ピーク II : 19-29,ピークIII : 30-38,ピー クIV : 39-44, ピークV $: 45-50$; 分）が認められた。 各ピークについてそれぞれウロン酸量を測定したとこ ろ, ピーク II に集中し歯槽骨で全ウロン酸量の $83 \%$, 非歯槽骨で $85 \%$ が認められ, 残りはボイドのピーク I に認められるのみでピーク III〜Vには殆ど認められな かった。なお，歯槽骨と非歯槽骨抽出物間のピーク II の溶出時間に差異が認められ, 歯槽骨抽出物は, 分子 量約 $300 \mathrm{kDa}$ の位置に, 非歯槽骨は分子量約 $540 \mathrm{kDa}$ の位置であった。

\section{3. 粗精製 PG 画分の SDS-PAGE}

図 5 に歯槽骨および非歯槽骨抽出物の HPLCによ り得られたピークIIの泳動結果を示す。歯槽骨, 非歯 槽骨ともにピークIIには他のピークとは様相を異にす る染色度の高い 2 つ明確なバンドが認められた。こ れらバンドは分子量約 $76 \mathrm{kDa}$ および $70 \mathrm{kDa}$ であっ た。更に, 歯槽骨抽出物ではこれら 2 つのバンドが各々 近接する 2 対のバンドとして認められた。他に, 染色 度の低い複数のバンドが $54 \mathrm{kDa}$ から $17 \mathrm{kDa}$ の位置 まで，歯槽骨，非歯槽骨ともに全てのピークにほほ同 

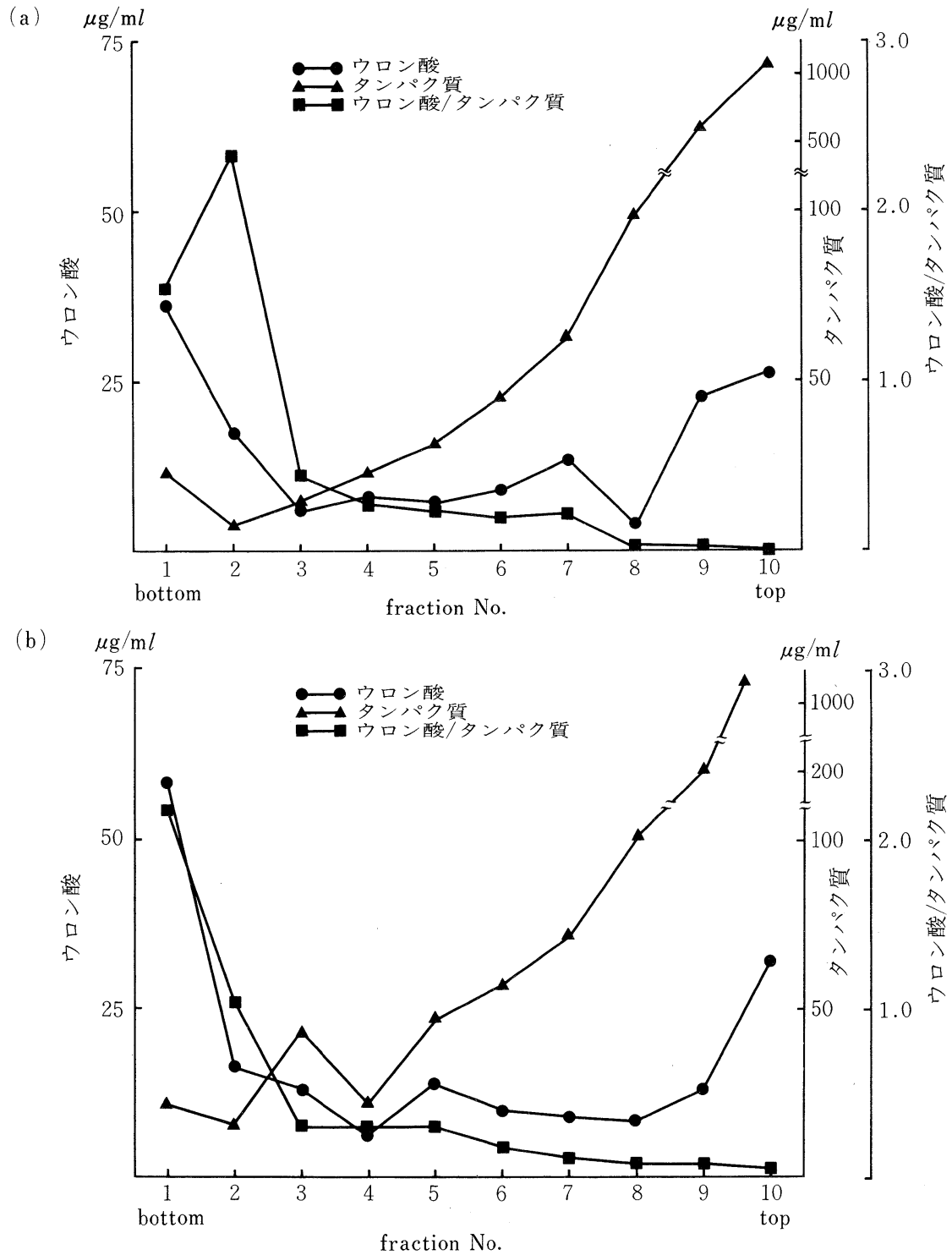

図 $3 \mathrm{CsCl}$ 沈降平衡遠心

（a）歯槽骨，（b）非歯槽骨 $\mathrm{CsCl} / 0.5 \mathrm{M}$ 塩酸グアニジン，比重 $1.6 \mathrm{~g} / \mathrm{m} l$

様に認められた。

\section{4. 粗精製 PG 画分 GAG のセルロースアセテート} 膜電気泳動

図 6 (a), (b ) に歯槽骨 GAG の 2 次元泳動像を示 す。低移動度の位置のブロードなスポットと，コンド ロイチン硫酸 $(\mathrm{CS})$ の位置に相当するアルシアンブ ルー強陽性のスポットが認められた。移動度の高いス ポットはコンドロイチナーゼによる酵素消化法で同定 を行った結果, CSであることが確認された。しかしな
がら移動度の低いスポットはいずれの GAG 分解酵素 にも消化されず残存し，今回このスポットをXとした (図 6-a)。その後, 微量成分検索のため同試料を濃縮 後, 再度電気泳動を行ったところ, 新たに 2 つのスポッ トが確認され, 酵素消化法によりデルマタン硫酸(DS) およびケラタン硫酸 $(\mathrm{KS})$ であることが確認された(図 6-b)。これら GAG の定量結果を表 2 に示す。歯槽骨の 主要 $\mathrm{GAG}$ は, CS であり全 GAG の 93\% $(183 \mu \mathrm{g} / \mathrm{g})$ を占め, 微量成分として DS が $5 \%(10.3 \mu \mathrm{g} / \mathrm{g}), \mathrm{KS}$ 


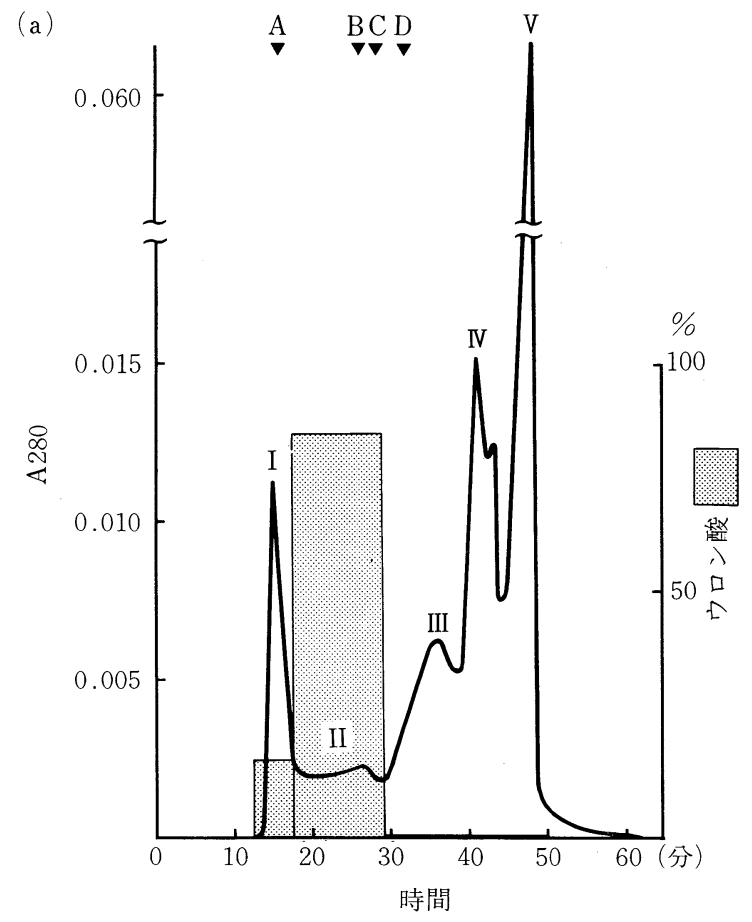

(b)

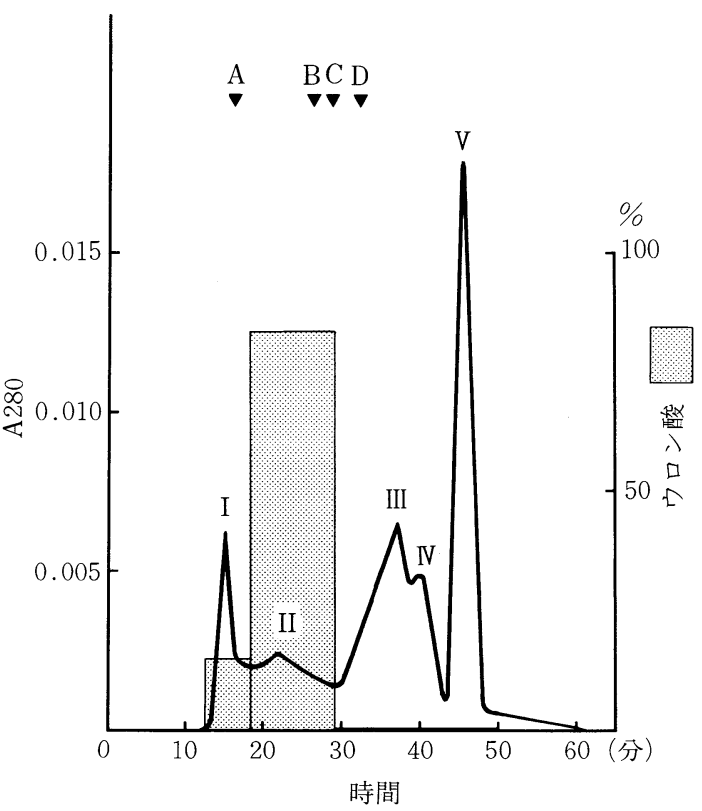

図 4 Superose 6 HR 10/30 のクロマトグラム

（a）歯槽骨，（b）非歯槽骨 溶媒; Gd-緩衝液 $/ 0.2 \%$ Triton X-100, 流速; $0.5 \mathrm{ml} / \mathrm{min}$, 検出; $280 \mathrm{~nm}$, 分子量マーカー ; A-チログロブリン (669k), B-フェリチン (440k), C-アルドラーゼ (158k), D-キモ トリプシノーゲン (25k), I〜V; ピークを示す。

が $1 \%(2.9 \mu \mathrm{g} / \mathrm{g})$ 存在した。非歯槽骨においても GAG 組成比は同様な值を示した $(\mathrm{CS}: 286 \mu \mathrm{g} / \mathrm{g}$, DS : 16.0 $\mu \mathrm{g} / \mathrm{g}, \mathrm{KS}: 5.0 \mu \mathrm{g} / \mathrm{g})$ が骨湿重量に対する GAG の存 在比率は約 1.6 倍と高い值を示した。なお, 図 6 ( a ), （b）は同条件で，GAG 標準試料を変えて行った。

\section{考察}

プロテオグリカン $(\mathrm{PG})$ の抽出には Termine ら ${ }^{18)}$ の 連続抽出法の他に $2 \mathrm{MCaCl}_{2}$ による抽出も可能であ $\eta^{24)}$ ，本法を用いてはウサギ歯槽骨から PG を抽出し ている ${ }^{15)}$ が, 至適濃度の幅が狭いなどの欠点があり, 塩 酸グアニジンが最も有効であるとされている。今回用 いた方法で，骨から抽出される成分は可溶性コラーゲ ンや非コラーゲン性有機質などであるが，そのうち Gd-extract 中には毛細血管や骨様基質 (osteoid)なぞ の非石灰化組織からの基質成分が， E-extract 中には 主としてハイドロキシアパタイトと親和性がある成分 が抽出される ${ }^{25,26)}$ 。本実験での歯槽骨および非歯槽骨
の Gd-extract と E-extract の総抽出量は，それぞれ もとの試料の湿重量に対して $1.52 \%, 1.67 \%$ とほぼ同 じであった。骨組織中での非コラーゲン性有機質の割

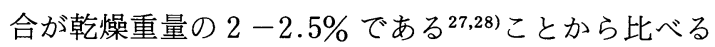
と若干低い值を示したが，試料の含水率の影響や脱灰 条件の差異，また対象とした動物の違いを考えるとほ ぼ一致していると思われる。総ウロン酸量は, 歯槽骨 に対して非歯槽骨が 2 倍以上の高い含有率を示した。 今回, 骨 PG 画分として実験に供した E-extractで, ウロン酸とともにタンパク質量も非歯槽骨に多く認め られたことは, GAG を構成成分の 1 つとして含む $\mathrm{PG}$ の含有率が高いことが考えられる。これは咀嚼等の機 能的な面を含む生理的環境の違いが, この $\mathrm{PG}$ 量の差 に影響を及ほしている可能性も考えられるが, 詳細は 不明である。量的差はあるものの，抽出段階で，見か け上の PG 量を表すウロン酸/タンパク質比が歯槽骨, 非歯槽骨ともに Gd-extract に対し E-extract が約 10 倍であったことから，骨組織からの PG が E-extract で効率よく抽出されたと考えられる。 


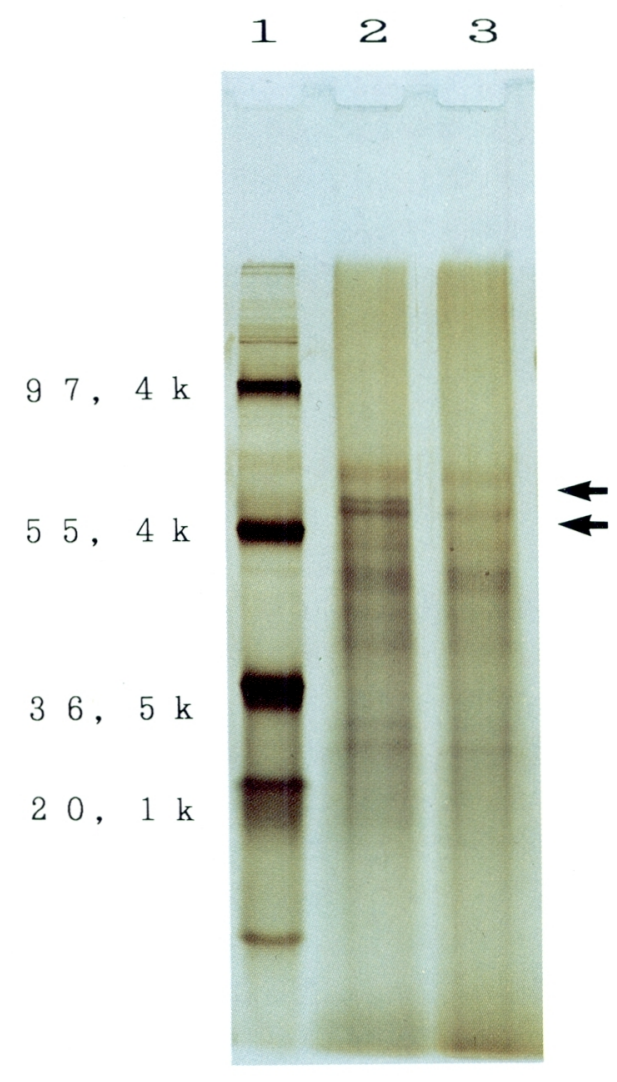

図 5 SDS-PAGE

1 ; 分子量マーカー, 2 ; 歯槽骨プロテオグリ カン， 3 ; 非歯槽骨プロテオグリカン。
$\mathrm{CsCl}$ 沈降平衡遠心において, 軟骨型 $\mathrm{PG}$ は遠心管底 部より $1 / 3$ に集中し, ウロン酸量にして約 $90 \%$ が底部 から $2 / 5$ までに, 一方 PG 以外のタンパク質は上部か ら2/5 までにほとんどが回収される ${ }^{29)}$ 。今回歯槽骨, 非 歯槽骨ともにA 1 およびA 2 にウロン酸の高いピー クが認められたこと，またタンパク質量が A 10 より 下部の画分に移行するに従いほぼ減少傾向を認めるが A 1 において再び増加すること,さらにA 1 および A 2 の総ウロン酸/タンパク質比が, 歯槽骨, 非歯槽骨 ともに約 1.8 であったことから，この画分にほぼ精製 された $\mathrm{PG}$ が存在すると考えられる。一方, A 9 および A 10 にはコアプロテインから分離した遊離の GAG 鎖, またはさらに分解され低分子化された糖鎖の存在 として考えられるウロン酸のピークが認められた。こ れは, 特定の酵素群による分解の可能性が考えられる

表 2 定量結果

\begin{tabular}{llllc}
\hline & HA & CS & DS & KS \\
\hline 歯槽骨 & n.d. & 183 & 10.3 & 2.9 \\
非歯槽骨 & n.d. & 286 & 16.0 & 5.0 \\
\hline & & & \multicolumn{3}{c}{$\mu \mathrm{g} / \mathrm{g}$ of bone }
\end{tabular}

HA : Hyaluronic Acid CS : Chondroitin Sulfate DS : Dermatan Sulfate KS: Keratan Sulfate n.d. : not detectable

数值は骨湿重量に対する值を示す。

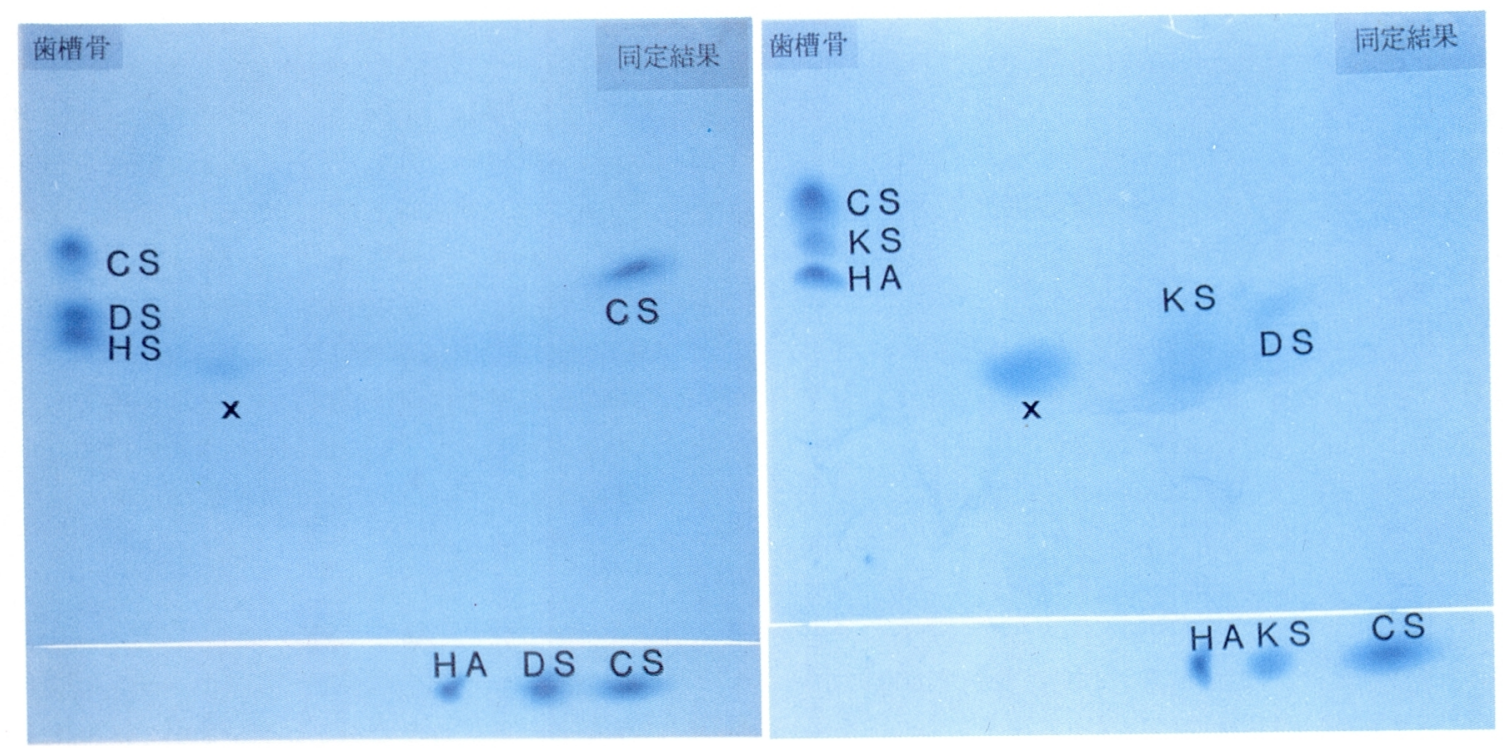

図 6 セルロースアセテート膜 2 次元電気泳動

歯槽骨プロテオグリカンの（a）濃縮前の泳動像，（b）濃縮後の泳動像。 
が, 本抽出操作は低温下でプロテアーゼインヒビター の存在下のもとで行ったものであるので, 試料を採取 した時点ですでにこの状態のものが存在している可能 性も考えられる。

粗精製 PG 画分の HPLC による溶出分離の結果, 歯 槽骨，非歯槽骨ともに，ピーク II 全ウロン酸量の約 85\% が集中して認められた。他はボイドとして認めら れるピーク I に確認された以外, ピークIII-Vでは殆 ど認められなかった。この事からピーク II が PGの ピークとして考えられる。骨組織の PG に関して Fisher ${ }^{30)}$ は，オリゴ糖の付き方の異なる分子量 38 $\mathrm{kDa}, 43 \mathrm{kDa}$ のコアタンパク質に $40 \mathrm{kDa}$ の糖鎖が 1 本または 2 本ついた約 80-120 kDa であると報告し ている。さらに糖鎖が 1 本鎖型のものと 2 本鎖型のも のは分子量が同じで，起源の異なるコアタンパク質に 結合しており，2本鎖型のものは幼若な骨組織中で多

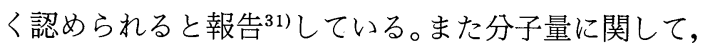
Franzen ら ${ }^{26)}$ は $74.6 \mathrm{kDa}$, Sato ら ${ }^{32)}$ は 70-120 kDa と報告している。しかしながら，ピーク II はその溶出 位置から分子量約 300-5 $50 \mathrm{kDa}$ と, 他の骨組織中で 見られるょうな低分子型 PGより大型のものとして分 離された。これは $\mathrm{Gd}$-緩衝液中では $0.2 \%$ Triton $\mathrm{X}$ -100 を含むものの PG 自体の会合能力が強いため, 見 かけ上の分子量がかなり大きなものとして捉えられて いる可能性がある。実際, 今回の SDS-PAGEの結果か らは, 本来の分子量はこれよりもかなり小さいもので あることが確認された。一方，ウロン酸の認められな かったピーク III〜Vは，溶出位置より $25 \mathrm{kDa}$ 以下の ポリペプチドとして認められた。これらは, 前述の $\mathrm{CsCl}$ 沈降平衡遠心 ${ }^{21)}$ では分離できなかった $\mathrm{PG}$ 以外 の夾雑タンパク質, あるいはゲル濾過カラムによる溶 出分離の操作途中で分解, 低分子化された PG 由来ポ リペプチドであると思われる。

HPLC 法により溶出分離し得られたピーク II の SDS-PAGE の泳動像は, 歯槽骨, 非歯槽骨ともに分子 量約 $70 \mathrm{kDa}$ 预よび $76 \mathrm{kDa}$ の位置に主要タンパクバ ンドが認められた。これは Fisher ら ${ }^{30)}$ の報告した糖鎖 が 1 本鎖型の PGの分子量に匹敵し，また Franzen ら ${ }^{26)}$ の報告にもほぼ一致した。更に歯槽骨 PGではそ の主要タンパクバンドが各々近接する 2 対のバンドと して認められた。この歯槽骨と非歯槽骨間での違いが, 部位特異的な分子種構成の差異を意味するものである か否かは現段階では明確ではない。今回, 粗精製 PG 画 分をさらにゲル濾過カラムによる HPLCで溶出分離
を行ったにもかかわらず, $54 \mathrm{kDa}$ 以下の範囲に複数の タンパクバンドが認められた。これは, PGの会合能力 の影響に起因するものか, 操作途中で分解, 低分子化 されたものかの何れかであると思われる。

一方，骨組織中の GAGに関しては，ヒアルロン酸 (HA), コンドロイチン硫酸 (CS), デルマタン硫酸 (DS), ヘパラン硫酸 $(\mathrm{HS})$, ケラタン硫酸 $(\mathrm{KS})$ など の存在が知られている ${ }^{16,25,26,32 \sim 34)}$ 。これら $\mathrm{GAG}$ 成分 の構成比については, 対象とする実験動物の種などに より若干の違いは認められるが, その主要 GAGはコ ンドロイチン-4-硫酸である事も報告15,17)されている。 歯槽骨においては, Waddington ら ${ }^{15}$ はウサギを用い て歯槽骨と支持骨とを分け GAGの定性定量を行い, 主要 GAG はコンドロイチン-4-硫酸と KS であり微 量成分は HA と DS である事を示した。さらに歯槽骨 には支持骨より多くの KS が存在する事を報告した。 また Bartold ${ }^{17)}$ はヒト, ブタ, ウサギの歯槽骨の構成 GAG について検討した結果, ヒト, ブタの主要 $\mathrm{GAG}$ は CS であり, ウサギの主要 $\mathrm{GAG}$ は CS と KS である と報告し, 主要 $\mathrm{GAG}$ においても種特異性のある事を 示した。今回の結果から, 主要 GAG は CS (93\%) で あり，その他の構成成分としてDS（5\%）も認められ た。これはウサギを除いた他の動物の歯槽骨の報 告 ${ }^{15,17)}$ に一致している。種特異性が強いと考えられる KS はごく微量が認められるのみであった。

ところで, GCF-GAG の供給源として考えられる他 の歯周組織中 $\mathrm{GAG}$ 構成について, 勝谷 ${ }^{35}$ はイ又歯肉 構成 GAG は HA (41\%), DS (48\%), CS (5\%), HS (6\%)であったと報告している。また岩田 $\left.{ }^{36}\right)$ は, 歯肉中 の GAG は炎症初期で HA と DS の減少を認めるが, 慢性炎症期では，健常時とほぼ同じ GAG 構成比を維 持する傾向を示した。歯根膜, およびセメント質中に も CS は認められるものの質的, 量的な面を考慮する と, GCF 成分に与える影響は低いと思われる。

この様に, 歯槽骨は歯周組織の中で CS の特徵的な 成分含有率を示し, 進行した歯周炎患者に特徵的にみ られる GCF-CS の供給源として大きな割合を占めて いるものと考えられる。

\section{結 論}

イヌ歯槽骨からプロテオグリカンを抽出し, 生化学 的検索を行い, 歯槽骨プロテオグリカンの特徵を非歯 槽骨プロテオグリカンとの比較において検討した。そ 
の結果，次の結論を得た。

1. 歯槽骨中のプロテオグリカンは脱灰条件下で, 効率よく抽出されたが, 抽出量は, 非歯槽骨部に対し て 1/2 以下であった。

2. 歯槽骨プロテオグリカンは分子量約 $76 \mathrm{kDa}$ と $70 \mathrm{kDa}$ の 2 種類の低分子型プロテオグリカンと推察 された。

3. 歯槽骨および非歯槽骨プロテオグリカン構成主 要グリコサミノグリカンはコンドロイチン硫酸であっ た。

以上の結果，歯槽骨プロテオグリカンは非歯槽骨プ ロテオグリカンと分子種構成をほぼ同じにするが，プ ロテオグリカン含有率が非歯槽骨部と比べて低いこと が認められた。さらにその主要グリコサミノグリカン はコンドロイチン硫酸であった。

尚, 本研究は平成 2 年度宮田奨励金の補助により行われ たことを付記する。

\section{文献}

1）梶川欽一郎：結合組織，第一版，金原出版，東京, 327, 1984.

2) Dorfman, A. : Studies on the biochemistry of connective tissue Pediatrics, $22: 576-589,1958$.

3) Koji Kimata, James H. Kimura, Eugene M.A. Thonar, Hans-J. Barrach, Stephen Rennard and Vincent C. Hascal : Swarmrat chondrosarcoma proteoglycans. J. Biol. Chem, $257: 3826,1982$.

4) Koji Kimata, Minoru Okayama, Atsushi Oohira and Sakaru Suzuki : Heterogeneity of proteochondroiti sulfates produced by chondrocytes different stages of cytodifferentiation: J. Biol. Chem, 249: 1646-1653, 1974.

5) Koji Kimata, Hans-J. Barrach, Kennch S. Brown and J.P. Pennypacke: Absence of proteoglycan core protein in cartilage from the $\mathrm{cmd} / \mathrm{cmd}$ (cartilage matrix deficiency) mouse. J. Biol. Chem., $256: 6961-6968,1981$.

6) Baggi, G.F. and Prodi, G. : Boll. Soc. Ital. Biol. Sper. $29: 1$, 1953. In International Review of Connective Tissue Research. (Hall, D.A., Editor), 2 : 304, 1954.

7) Delaunay, A. and Bazin, S. : Mucopolysaccharids, Collagen, nonfibrillar proteins In inflammation. In International Review of Connetive Tissue Research. (Hall, D.A., Editor), $2: 306,1964$.

8) Polson, A.M. and Goodson, J.M. : Periodontal diagnosis. Current status and future needs. J. Periodontol., 56 : 25-34, 1985.
9）梶川 潔：イヌの実験的歯周炎に打ける歯肉溝滲出 液中のグリコサミノグリカンについて，日歯周誌， $28: 500-515,1986$.

10) Last, K.S., Stanbury, J.B. and Embery, G. : Glycosaminoglycans in human gingival crevicular fluid as indicators of active periodontal disease. Archs Oral Biol., 30 : 275-281, 1985.

11) Embery, G., Oliver, W.H., Stanbury, J.B. and Purvis, J.A. : The electro phoretic detection of acidic glycosaminoglycans in human gingival sulcus fluid. Archs Oral Biol., 27 : 177-179, 1982.

12）梶川 潔, 永橋理宏, 水野清, 白木雅文, 岩山幸 雄：七トの実験的歯肉炎に扔年歯肉溝洷出液中の グリコサミノグリカンについて. 日歯周誌, $29: 844$ $-852,1987$.

13）永橋理宏：歯周初期治療による歯肉溝溼出液グリコ サミノグリカンの変動。 日歯周誌, $32: 422-433$, 1990.

14) K.S. Last, C. Donkin and G. Embery: Glycosaminoglycans in human gingival crevicular fluid during orthodontic movement., $33: 907-912$, 1988.

15) Waddington, R.J., Embery, G. and Last, K.S. : The glycosaminoglycan constituents of alveolar and basal bone of the rabbit. Connect. Tissue Res., $17: 171-180,1988$.

16) Bartold, P.M. : Proteoglycan of the periodontium : Structure, role and function. J. Periodont. Res., $22:$ 431-444, 1987.

17) Bartold, P.M. : A biochemical and immunohistochemical study of the proteoglycans of alveolar bone. J Dent Res., 67 : 7-19, 1990.

18) Termine, J.D., Belcourt, A.B., Christner, P.J., Conn, K.M. and Nylen, M.U. : Properties of dissociatively extracted fetal tooth matrix proteins. I. Principal molecular species in developing bovine enamel. J. Biol. Chem. $255:$ 9760-9768, 1980.

19) Lowry, O.H., Resebrough, N.J., Farr, A.L. and Randall, R.J. : Protein measurement with the folin phenol regont. J. Biol. Chem. 193 : 265-275, 1951.

20) Bitter, T. and Muir, H.N. : A modified uronic acid carbazole reaction. Anal. Biochem. $4: 330-334$, 1962.

21) Lawrence L. Faltz, A. Hari Reddi, Gretchen K. Hascall, Damon Martin, Julio C. Pita and Vincent C. Hascall: Characteristics of proteoglycans extracted from the swarm rat chondrosarcoma with associative solvents., $254: 1375-1380,1979$.

22) Laemmli, U.K. : Cleavage of Structural proteins during the assembly of the head of bacteriophage T 4. Nature $227: 680-685,1970$.

23) Hata, R. and Nagai, Y.: A rapid and micro method for separation of acidic glycosaminoglycans by two-dimensional electrophoresis. Anal, Biochem., 45 : 462-468, 1972.

24）新名正由：軟骨プロテオグリカン研究手技, 整形・災 
害外科, $26: 1409-1424,1983$.

25) Franzen, A. and Heingard, D. : Extraction and purification of proteoglycans from mature bovine bone. Biochem. J., $224: 47-58,1984$.

26) Franzen, A. and Heingard, D. : Characterization of proteoglycans from the calcified matrix of bovine bone. Biochem. J., 224: 59-66, 1984.

27) Eastoe, J.E. : The organic matrix of bone, In : The Biochemistry and Physiology of Bone. Bourne, G. H., Editor, Academic Press, New York, 81-105, 1956.

28) Oldroyd, D. and Herring, G.M. : A method for the study of bone mucosubstances by using collagenase. Biochem. J., $104: 20$ P, 1967.

29）木全弘治：軟骨のプロテオグリカン, 日本生化学会 編. 複合糖質研究法 II, 東京化学同人, 東京, 253$263,1986$.

30) Fisher, L.W., Termine, J.D., Dejter, Jr. S.W., Whitson, S.W., Yanagishita, M., Kimura, J.H., Hascall, V.C., Kleinman, H.K., Hassell, J.R. and Nilsson, B. : Proteoglycans of developing bone. J.
Biol. Chem., 258 : 6588-6594, 1983.

31) Fisher, L.W.: The Nature of the proteoglycans of bone. In The Chemistry and Biology of Mineralized Tissues, Butler, W.T., Editor Alabama Ebsco Media, 188-196, 1985.

32) Sato, S., Rahemtulla, F., Prince, C.W., Tonana, M. and Butler, W.T. : Proteoglycans of adult bovine compact bone. Connect. Tissue Res., 14:65-75, 1985.

33) Herring, G.M. : Studies on the protein-bound chondroitin Sulfate of bovine cortical bone. Biochem. J., $107:$ 41-49, 1968.

34) Prince, C.W. Rahemtulla, F. and Butler, W.T. : Metabolism of rat bone proteoglycan in vivo. Biochem. J., 216:589-596, 1983.

35）勝谷芳文：イヌの実験的歯周炎における歯肉グリコ サミノグリカン代謝について。 日歯周誌, $24: 266^{-}$ 284, 1982.

36）岩田 眞：イ邓の実験的歯周炎に扔引る歯肉上皮な らびに上皮下結合組織のグリコサミノグリカンにつ いて. 日歯周誌, $30 ： 1008-1020,1988$.

\section{連絡先：}

朝日大学歯学部歯周病学講座

テ 501-02 岐阜県本巣郡穂積町穂積 1851 